\title{
Investigation of lime usage impacts on bauxite processability at ETI Aluminyum Plant
}

\author{
Hüseyin Arıkan ${ }^{1} \cdot$ Gökhan K. Demir ${ }^{2}$. Sema Vural ${ }^{3}$ (1)
}

Received: 29 March 2018 / Accepted: 3 February 2019 / Published online: 11 February 2019

(c) The Author(s) 2019

\begin{abstract}
ETI Aluminyum A.Ş., the primary aluminium manufacturer of Turkey, is also one of the major integrated plants of the world capable of performing production from mining until end product. The alumina refinery was designed on a certain boehmitic bauxite quality basis. However, bauxite properties have changed over the years, resulting in the urgent need for process optimization to not only keep the refinery cost efficient, but also prevent serious bottlenecks in the near future. Lime can be used to overcome problems when using bauxites with specific and variable chemical and mineralogical characteristics. Although lime is extensively used when processing diasporic bauxites, the studies on boehmitic bauxites and the overall effects on the process are limited. In this paper, lime impact was investigated at all stages of the Bayer process including the effect on alumina quality, energy and raw material consumptions. The results showed significant improvements in the product quality as well as recordable savings on consumptions.
\end{abstract}

Keywords Bayer process $\cdot$ Lime usage $\cdot$ Caustic consumption $\cdot$ Digestion $\cdot$ Alumina quality $\cdot$ Boehmitic bauxite

\section{Introduction}

The Bayer process is used for producing alumina $\left(\mathrm{Al}_{2} \mathrm{O}_{3}\right)$ from bauxite ore. The process was developed and patented by Karl Josef Bayer in 1887 [1], which led to a dramatic reduction in the cost of aluminium metal. The process involves the following operations: mining, dissolution of the alumina at elevated temperatures, the addition of flocculants, precipitation of pure gibbsite, regeneration of the solutions for recycling, calcination of the gibbsite to give alumina [2]. All these operations are related to the chemical composition of the bauxite combination. Gibbsite is aluminium hydroxide $\left(\mathrm{Al}(\mathrm{OH})_{3}\right)$, while boehmite and diaspore are both aluminium-oxide-hydroxides $(\mathrm{AlO}(\mathrm{OH}))$. The main difference between the latter two is that diaspore has a different

Sema Vural

semavural@gmail.com; svural@erbakan.edu.tr

1 Seydisehir AC Engineering Faculty, Department of Mechanical Engineering, Necmettin Erbakan University, Konya, Turkey

2 ETI Aluminium Inc, 42370 Seydişehir/Konya, Turkey

3 Seydisehir AC Engineering Faculty, Department of Materials and Metallurgical Engineering, Necmettin Erbakan University, Konya, Turkey crystalline structure to boehmite. Differences in ore composition and presence of iron, silicon and titanium impurities influence their subsequent processing [3, 4]. Thus, it is necessary to design the process according to the bauxite source.

ETI Alüminyum, founded in 1973, is a vertically integrated company located in Seydisehir, Konya, in the central Anatolia region of Turkey. The facility currently has the capacity to treat 550,000 tonnes of bauxite per year to produce 400,000 tonnes/year of aluminium hydroxide, 250,000 tonnes/year of calcined alumina and 80,000 tonnes/year of primary aluminium.

Although the initial $\mathrm{A} / \mathrm{S}\left(\mathrm{Al}_{2} \mathrm{O}_{3} / \mathrm{SiO}_{2}\right)$ ratio of bauxite reserves was around 7.50, it has decreased to 7.05 over the years which mean less amount of alumina can be produced with the same energy. Additionally, the caustic quantity needed for dissolution of alumina and the amount of the red mud residue have increased [5, 6]. ETI aluminium has faced not only decreasing A/S ratio, but also diaspore- and goethite-rich bauxite ores during the processing of new mines such as Arvana and Kakliktas. Therefore, as more and more diaspore- and goethite-rich bauxites are imported into ETI, great attention has been paid to the processing of these bauxites in recent years and essential updates are required to keep manufacturing in the acceptable cost range. 
Lime is widely used as an additive in alumina production by the Bayer process, as it provides higher alumina recovery and lower caustic soda consumption [3, 4], controlling impurities and minimizing the inhibiting effect of sodium titanates [7-9], promoting settling and filtering properties of the red mud $[10,11]$. Although lime is extensively used with diasporic and gibbsitic bauxites $[2,11,12]$, the published data on boehmitic bauxites and the overall effects on the process are limited [13].

In this study, we investigated the effect of lime usage on the Arvana and Kakliktas bauxites. The studies were performed to understand the effects in the whole process such as digestion, settling and decomposition, as well as effects on energy and raw material consumptions.

\section{Experimental}

Different bauxite samples representing boehmitic and diasporic type were collected from the Arvana and Kakliktas ores. Diasporic bauxite was rich in goethite content in both samples as well.

The bauxite, red mud and alumina samples were characterized chemically by Thermo ARL Advan'x 9800 X-Ray Fluorescence (XRF). The XRF device was calibrated with the standard reference bauxite samples such as Alcan BXT09, NIST 69b, GIH-BaH 69 b, CETEM BXGO-2, CETEM BXMO-3 and CETEM BXMG-6 before bauxite characterization tests. For the red mud characterization tests, Alcan RM-01, Alcan RM-04 and Alcan RM-08, and for the obtained alumina samples, Alcan ALU-01, Alcan ALU-04, Alcan ALU-06 and Alcan ALU-10 standard samples were used.

Bauxite samples crushed to minus $25 \mathrm{~mm}$ with hammer crusher were obtained from alumina plant and then ground with a Herzog HSM 100 ring mill to under $53 \mu \mathrm{m}$ fractions. $0.4 \mathrm{~g}$ of finely ground and oven-dried powders was put into platinum crucibles with $6 \mathrm{~g}$ accurately weighed 33-67 lithium metaborate/tetraborate flux. The mixture was fused in Claisse-M4 Fusion device and the cooled glass discs were analysed on XRF. Red mud and alumina samples did not need to be crushed or ground due to their fineness. The same method was used to prepare these samples. LOI $\left(100-1000{ }^{\circ} \mathrm{C}\right)$ was measured by weight loss of dried samples using a LECO TGA 601.

The bauxite and red mud samples were also characterized mineralogically by GNR Explorer X-Ray Diffraction (XRD). Crushed, ground and oven-dried samples were pressed into stainless steel rings with Herzog Press. $40 \mathrm{kV}$ and $35 \mathrm{~mA}$ energy with a $\lambda$ value of 1.5406 was used. X-ray scanning was done between 5 and 702 theta $(2 \theta)$ range and $0.4 / 2$ sc scanning rate and analysed by Match programme. The intensity of XRD peaks and minerals were evaluated with $\mathrm{XRF}$ results and semi-quantitative results were obtained.

Synthetic and process caustic liquors were used as digestion liquor. Calculated amounts of digestion liquor was added to ground bauxite and digested under pressure in Parr autoclaves. The digested slurry was taken and separated as solid and liquid phase through washing and filtration processes. The liquid phase was analysed in a Metrohm 905 and 809 Titrando potentiometric titrator with Tiomo 2.3 software to determine the concentration of $\mathrm{Al}_{2} \mathrm{O}_{3}$ and $\mathrm{Na}_{2} \mathrm{O}$. This potentiometric titrator was calibrated with Metrohm, $\mathrm{pH}$ 4, 7, 9 buffer solutions before tests. Solid phase was analysed through XRF and XRD. Alumina recovery from solid phase was calculated according to bauxite analysis. Digested slurry was also diluted to $140 \mathrm{~g} / \mathrm{L} \mathrm{Na} \mathrm{Na}_{2} \mathrm{Oc}$ [caustic alkali $\left.\left(\mathrm{NaOH}+\mathrm{NaAl}(\mathrm{OH})_{4}\right)\right]$ concentration with hot deionized water. The diluted slurry was then treated with coagulants and flocculants to settle red mud from liquid. The settling rate and suspended solids of extracted liquor were determined to evaluate the settling performance of red mud.

Red mud particle size distribution was analysed according to Mie theorem with Malvern Mastersizer 3000 equipped with Hydro MV wet measurement device using the ISO 13320 standard method. Deionized water was used as dispersant. The liquid phase after the settling test was seeded with aluminium hydroxide crystals and aluminium hydroxide was allowed to precipitate over a period of $72 \mathrm{~h}$. The aluminium hydroxide obtained was filtered and calcined to produce alumina. Alumina was analysed with XRF to compare impurity changes in the product.

\section{Results and discussion}

\section{Bauxite characterization}

The studies were executed on two types of bauxite samples. Bauxite-1 is boehmitic type and has a moderate $\mathrm{A} / \mathrm{S}$ ratio of 7.51, while bauxite- 2 is diasporic type and has a high $\mathrm{A} / \mathrm{S}$ ratio of 14.7. Bauxite- 2 can be assumed to be of high quality, according to XRF analysis. However, it has a high diaspore and goethite content which may affect digestion and settling behaviours. Haematite to goethite ratio $(\mathrm{H} / \mathrm{G})$ is an indicator of settling performance of bauxite residue (red mud): higher the bauxite, the better is it for the Bayer process. Tables 1 and 2 show the chemical and mineralogical analysis of crude bauxites.

\section{Digestion tests}

Bauxite-1 was digested with and without lime addition at different digestion temperatures in $1 \mathrm{~L}$ Parr bomb reactors. Digestion liquor composition: $\mathrm{Al}_{2} \mathrm{O}_{3}=112.2 \mathrm{~g} / \mathrm{L}$, 
$\mathrm{Na}_{2} \mathrm{O}_{\mathrm{c}}=252.4 \mathrm{~g} / \mathrm{L}$, caustic/total soda ratio $(\mathrm{C} / \mathrm{S})=0.948$, caustic ratio $\left(\mathrm{Na}_{2} \mathrm{O}_{\mathrm{c}} / \mathrm{Al}_{2} \mathrm{O}_{3}\right.$ molar ratio- $\left.\mathrm{MR}\right)=3.70$, lime quality, $\mathrm{CaO}=92.0 \%$, reaction time $=2 \mathrm{~h}$.

Alumina recovery and caustic consumption values after digestion reactions are given in Fig. 1.

Both alumina recovery and $\mathrm{Na}_{2} \mathrm{O} / \mathrm{SiO}_{2}$ ratio of red mud increase with increase in temperature in case of no lime usage. This can be explained by temperature having a significant effect on the dissolution of alumina and therefore increasing the diffusion of digestion liquor on bauxite [14].
Therefore, as bauxite breaks down to smaller pieces, new surface area opens and the digestion liquor reacts with either alumina or silica minerals easily. As given in Table 3, higher digestion temperatures result in finer red mud, which has higher surface area [15]. However, higher temperatures can cause problems at red mud settling and washing stages.

Before the digestion, addition of $2.11 \%$ lime to the bauxite samples decreases the alumina recovery and increases the $\mathrm{Na}_{2} \mathrm{O} / \mathrm{SiO}_{2}$ ratio of red mud with increase in temperature. The highest alumina recovery and the lowest $\mathrm{Na}_{2} \mathrm{O} / \mathrm{SiO}_{2}$
Table 1 Chemical analysis of crude bauxite samples

\begin{tabular}{llllllr}
\hline Sample & \multicolumn{2}{l}{ a XRF analysis, $\%$} & \multicolumn{2}{c}{ A/S ratio } \\
\cline { 2 - 6 } & $\mathrm{Al}_{2} \mathrm{O}_{3}$ & $\mathrm{SiO}_{2}$ & $\mathrm{Fe}_{2} \mathrm{O}_{3}$ & $\mathrm{TiO}_{2}$ & $\mathrm{CaO}$ & \\
\hline Bauxite-1 & 57.14 & 7.61 & 17.84 & 2.59 & 0.41 & 7.51 \\
Bauxite-2 & 59.65 & 4.06 & 18.25 & 2.80 & 0.32 & 14.69 \\
\hline
\end{tabular}

${ }^{\mathrm{a}}$ Mean of two analyses; the standard deviation ranges were as follows: $\mathrm{Al}_{2} \mathrm{O}_{3}: 0.29 \%, \mathrm{SiO}_{2}: 0.09 \%, \mathrm{Fe}_{2} \mathrm{O}_{3}$ : $0.31 \%, \mathrm{TiO}_{2}: 0.07 \%, \mathrm{CaO}: 0.02 \%$

Table 2 Mineralogical analysis of crude bauxite samples

\begin{tabular}{|c|c|c|c|c|c|c|c|c|c|c|c|}
\hline \multirow[t]{2}{*}{ Sample } & \multicolumn{10}{|c|}{ XRD analysis (\%) } & \multirow[t]{2}{*}{$\mathrm{H} / \mathrm{G}$ ratio } \\
\hline & Boehmite & Diaspore & Gibbsite & Tyridimide & Quartz & Haematite & Goethite & Anatas & Calcite & Amorphous & \\
\hline Bauxite-1 & 60.57 & 1.21 & 0.43 & 10.83 & 2.33 & 0.13 & 0.82 & 2.05 & 1.15 & 3.36 & 20.27 \\
\hline Bauxite-2 & 13.97 & 54.31 & 0.92 & 2.53 & 2.23 & 0.66 & 12.83 & 1.86 & 0.57 & 2.47 & 0.55 \\
\hline
\end{tabular}

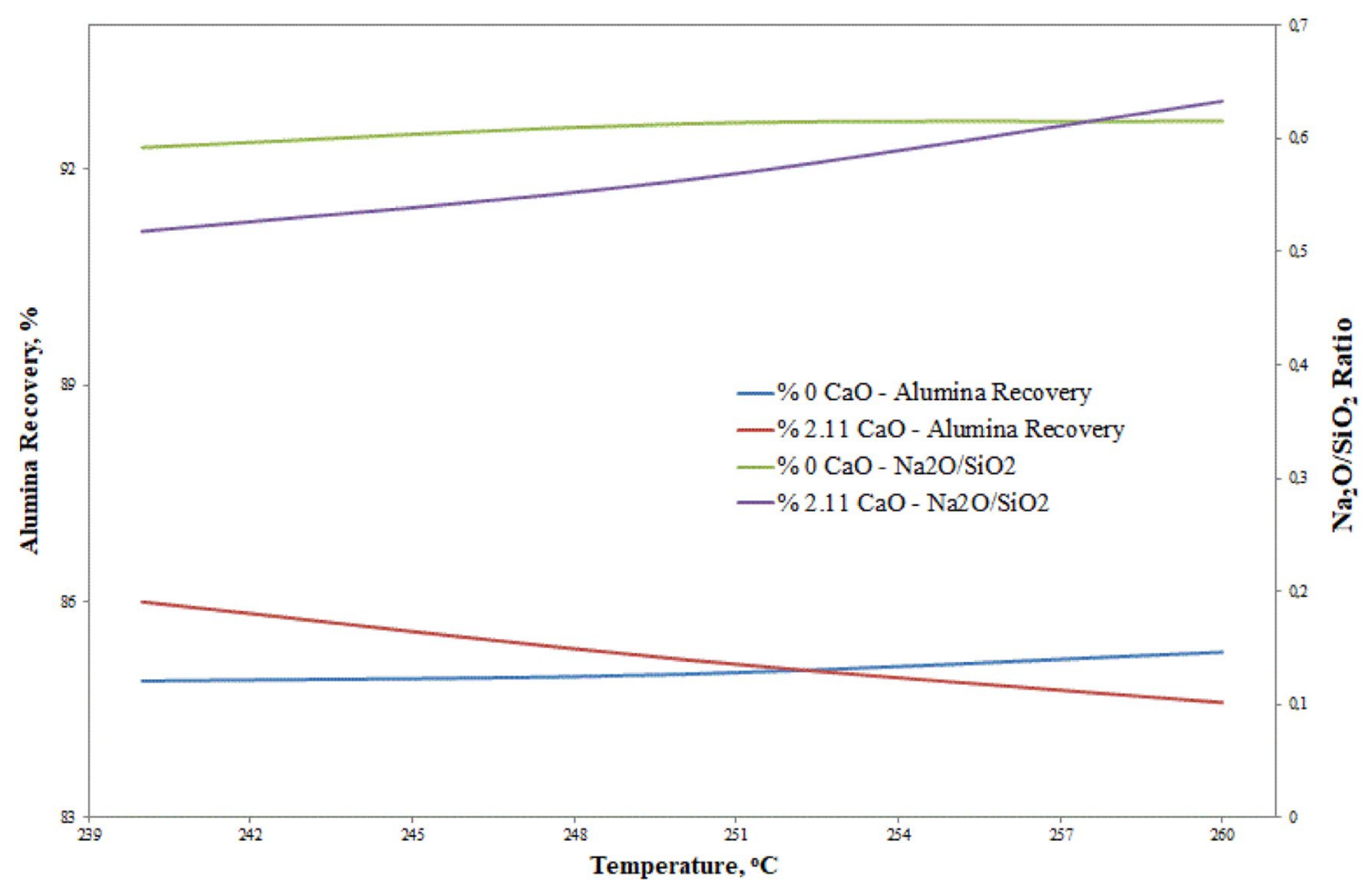

Fig. 1 Lime impact on alumina recovery and $\mathrm{Na}_{2} \mathrm{O} / \mathrm{SiO}_{2}$ ratio of red muds at different digestion temperatures 
Table 3 Red mud particle size distribution

\begin{tabular}{llllllll}
\hline $\begin{array}{l}\text { Tempera- } \\
\text { ture }\left({ }^{\circ} \mathrm{C}\right)\end{array}$ & $\mathrm{CaO}$ dosage $(\%)$ & \multicolumn{6}{l}{ Red mud particle size distribution $(\%)$} \\
\cline { 3 - 7 } & & $\mathrm{D} 50(\mu \mathrm{m})$ & $+149(\mu \mathrm{m})$ & -149 & -74 & -44 & $-20(\mu \mathrm{m})$ \\
& & & & $+74(\mu \mathrm{m})$ & $+44(\mu \mathrm{m})$ & $+20(\mu \mathrm{m})$ & \\
\hline 240 & 0 & 2.74 & 0.01 & 2.23 & 1.85 & 2.27 & 93.64 \\
240 & 2.11 & 4.02 & 0.48 & 3.96 & 4.27 & 8.78 & 82.51 \\
250 & 0 & 2.67 & 0 & 0 & 0.02 & 2.98 & 97.00 \\
250 & 2.11 & 3.26 & 0.12 & 1.67 & 1.50 & 4.79 & 91.92 \\
260 & 0 & 2.22 & 0 & 0 & 0.20 & 1.10 & 98.70 \\
260 & 2.11 & 3.01 & 0 & 0.61 & 1.61 & 6.52 & 91.26 \\
\hline
\end{tabular}

ratio were achieved at $240{ }^{\circ} \mathrm{C}$. It can be explained that lime partly reacts with silica in the bauxite and prevents sodium silicate formation $[16,17]$. Then it provides alumina dissolution increase. This takes place at lower temperatures more effectively. Increasing temperature promotes sodium aluminosilicate formation and excess lime reacts with alumina minerals forming calcium alumina silicate derivatives, which cause lower alumina recovery. Therefore, the worst alumina recovery and $\mathrm{Na}_{2} \mathrm{O} / \mathrm{SiO}_{2}$ ratio values were observed at $260{ }^{\circ} \mathrm{C}$.

On the other hand, getting lower caustic ratio after digestion which means higher supersaturated liquor for the decomposition process of sodium aluminate liquor is another important parameter. Higher supersaturation provides higher yield and coarser product in decomposition circuit. According to the results shown in Fig. 3, the lowest caustic ratio was obtained at $240{ }^{\circ} \mathrm{C}$ digestion temperature with lime usage.

Different lime dosages were applied to Bauxite-1 sample to investigate the changes in both alumina recovery and $\mathrm{Na}_{2} \mathrm{O} / \mathrm{SiO}_{2}$ ratio of red mud. Digestion temperature was $240{ }^{\circ} \mathrm{C}$ and other variables were kept the same as mentioned above (Fig. 2).

Linear regression shows that there is a strong correlation between alumina recovery and the $\mathrm{Na}_{2} \mathrm{O} / \mathrm{SiO}_{2}$ ratio of red mud versus lime dosage. Both alumina recovery and $\mathrm{Na}_{2} \mathrm{O} / \mathrm{SiO}_{2}$ ratio decrease with increase in lime dosage. But it is critical that decrease in $\mathrm{Na}_{2} \mathrm{O} / \mathrm{SiO}_{2}$ ratio is steeper than alumina recovery. Accepting nearly $10 \%$ loss of alumina recovery, the caustic content of red mud becomes almost

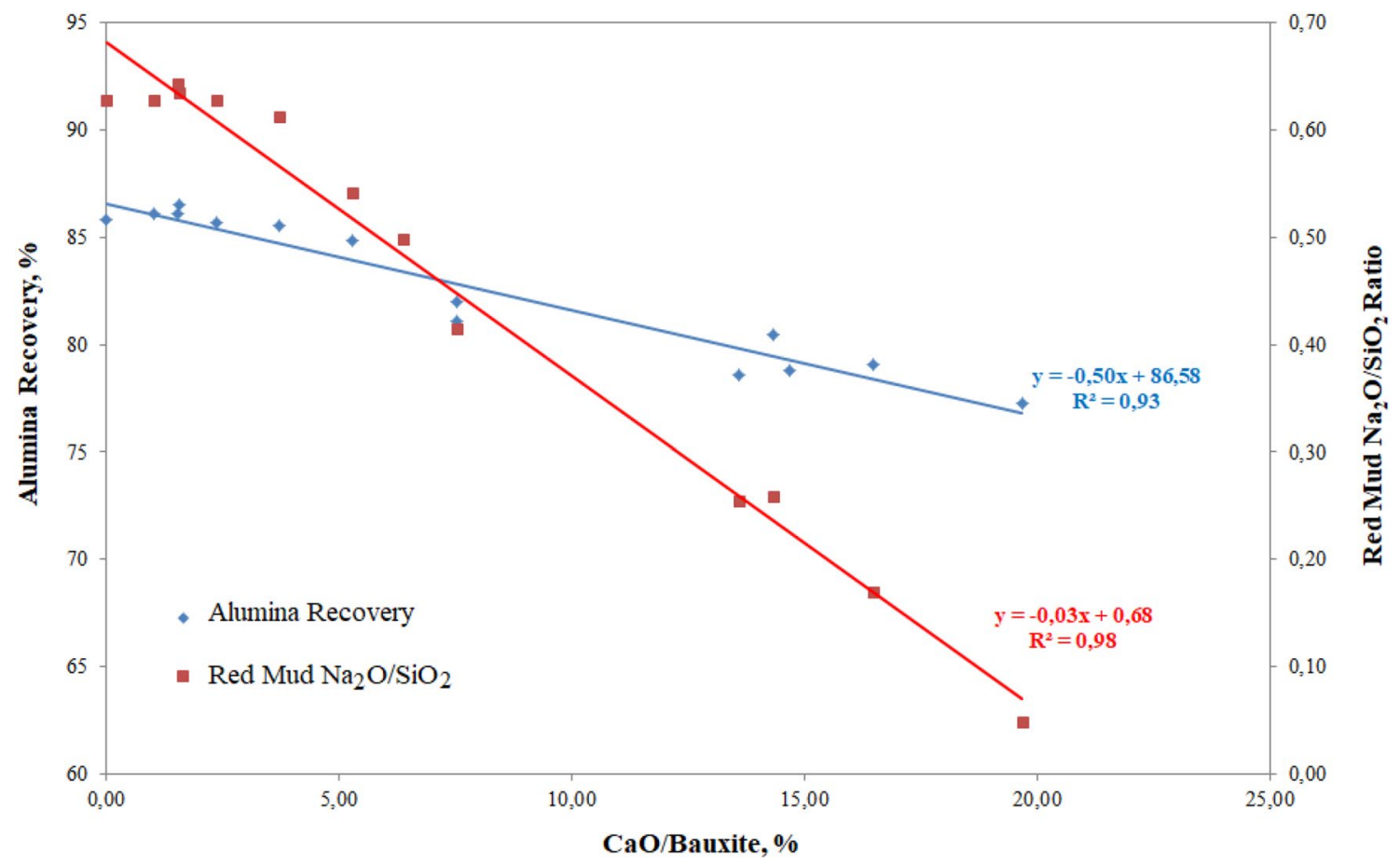

Fig. 2 Lime dosage effect on alumina recovery and $\mathrm{Na}_{2} \mathrm{O} / \mathrm{SiO}_{2}$ ratio of red mud 


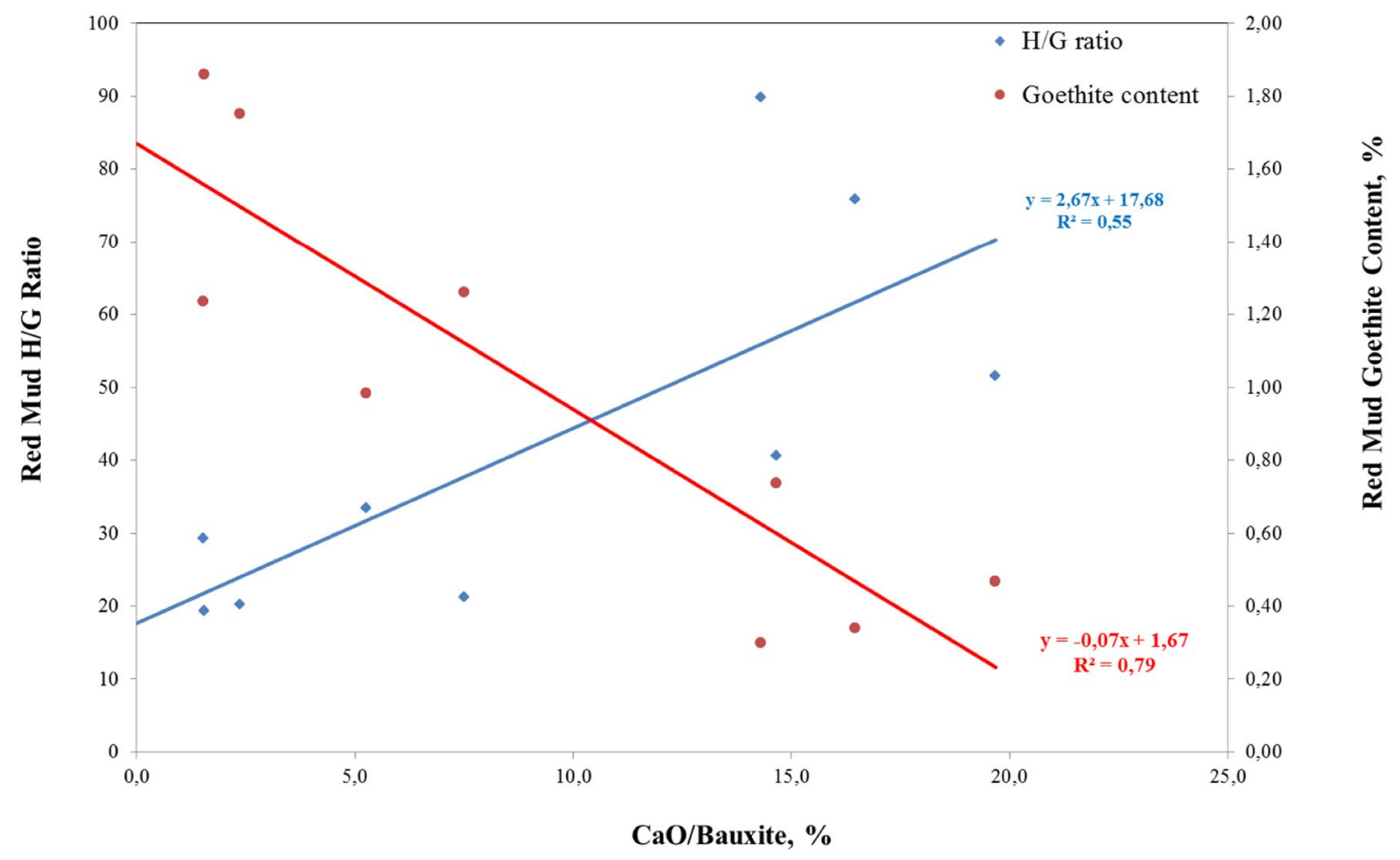

Fig. 3 Lime dosage effect on H/G ratio and goethite content of red mud

zero. Significant caustic savings can be obtained if the lime dosage is optimized according to alumina losses.

The $\mathrm{H} / \mathrm{G}$ ratio of red mud obtained after Bauxite-1 digestion has been monitored at different lime charges (Fig. 3).

According to the results in Fig. 3, there is a positive linear relationship between $\mathrm{H} / \mathrm{G}$ ratio and negative linear relationship between goethite content versus lime dosage. The higher lime dosage results in a higher $\mathrm{H} / \mathrm{G}$ ratio in red mud, while the goethite content can be decreased significantly. This effect can be seen especially at a lime dosage more than $10 \%$. It also provides a big advantage to manage the settling and washing stages of the Bayer process. The results show that goethite can be hydrothermally converted to haematite more easily at higher lime dosages.

Bauxite- 2 was digested with and without lime addition at different caustic concentrations in $75 \mathrm{~mL}$ Parr bomb reactors. Synthetic digestion liquor composition: $\mathrm{Na}_{2} \mathrm{O}_{\mathrm{c}}=127.9 \mathrm{~g} / \mathrm{L}$, $\mathrm{SiO}_{2}=0.48 \mathrm{~g} / \mathrm{L}$; process digestion liquor composition: given in Fig. 4; lime quality: $\mathrm{CaO}=93.0 \%$; reaction temperature $=250{ }^{\circ} \mathrm{C}$; reaction time $=2 \mathrm{~h}$.

Alumina recovery values are given against digestion caustic ratio in Fig. 4.

In general, diasporic bauxite is digested at high temperature and high caustic concentration. Currently, ETI Aluminyum AS carries on the process at $250{ }^{\circ} \mathrm{C}$ digestion temperature with 200-260 g/L Na2Oc digestion liquor caustic concentration. The digestion caustic ratio target is $1.34 \pm 0.02$. As mentioned previously, the lower caustic ratio after digestion means a higher decomposition yield, namely lower production cost. As it is clear in Fig. 4, it is impossible to achieve lower ratios due to diaspore equilibrium solubility in caustic liquor. The achievable ratio with a lower alumina recovery in case of no lime usage is 1.49 . As the caustic ratio was increased, higher alumina recovery values were observed. The highest alumina recovery achieved by synthetic liquor usage was $93.7 \%$.

Lime usage $(5 \%)$ with $260 \mathrm{~g} / \mathrm{L} \mathrm{Na}_{2} \mathrm{O}_{\mathrm{c}}$ digestion liquor caustic concentration resulted in approximately the same alumina recovery $(93.1 \%)$ as achieved with synthetic liquor. Compared with the synthetic liquor usage which gave the best alumina recovery, the digestion caustic ratio was also lower at the lime usage as an extra advantage. Lime usage provides a catalytic effect and assists in alumina dissolution [18, 19]. Additionally, it affects the caustic content of red mud as well (Fig. 5).

Addition of $5 \%$ lime decreases the $\mathrm{Na}_{2} \mathrm{O} / \mathrm{SiO}_{2}$ ratio of red mud from 0.6 to 0.1 . The caustic content of red mud with lime usage is almost zero. At the same time, the higher digestion liquor caustic concentration means a higher caustic content in red mud in the absence of lime. On the contrary, in the presence of lime, it is vice versa.

The $\mathrm{H} / \mathrm{G}$ ratio is an important issue in bauxite. Lime addition has a large impact on this ratio (Fig. 6).

Goethite mineral can be hydrothermally converted to haematite over $300{ }^{\circ} \mathrm{C}$ reaction temperatures [20]. However, lime behaves as a catalyst during this conversion $[11,19,21$, 


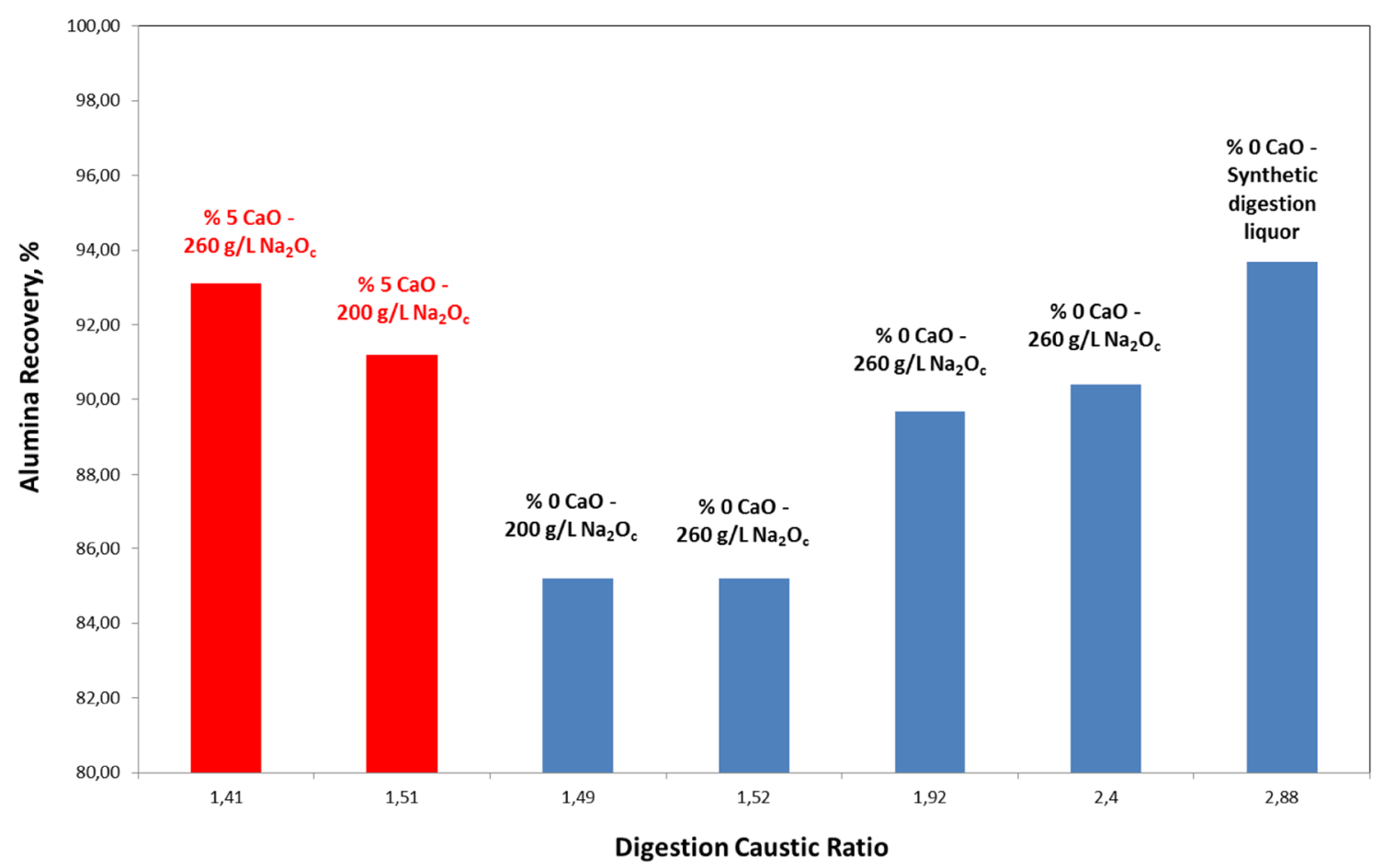

Fig. 4 Alumina recovery values at different caustic concentrations and ratios with and without lime

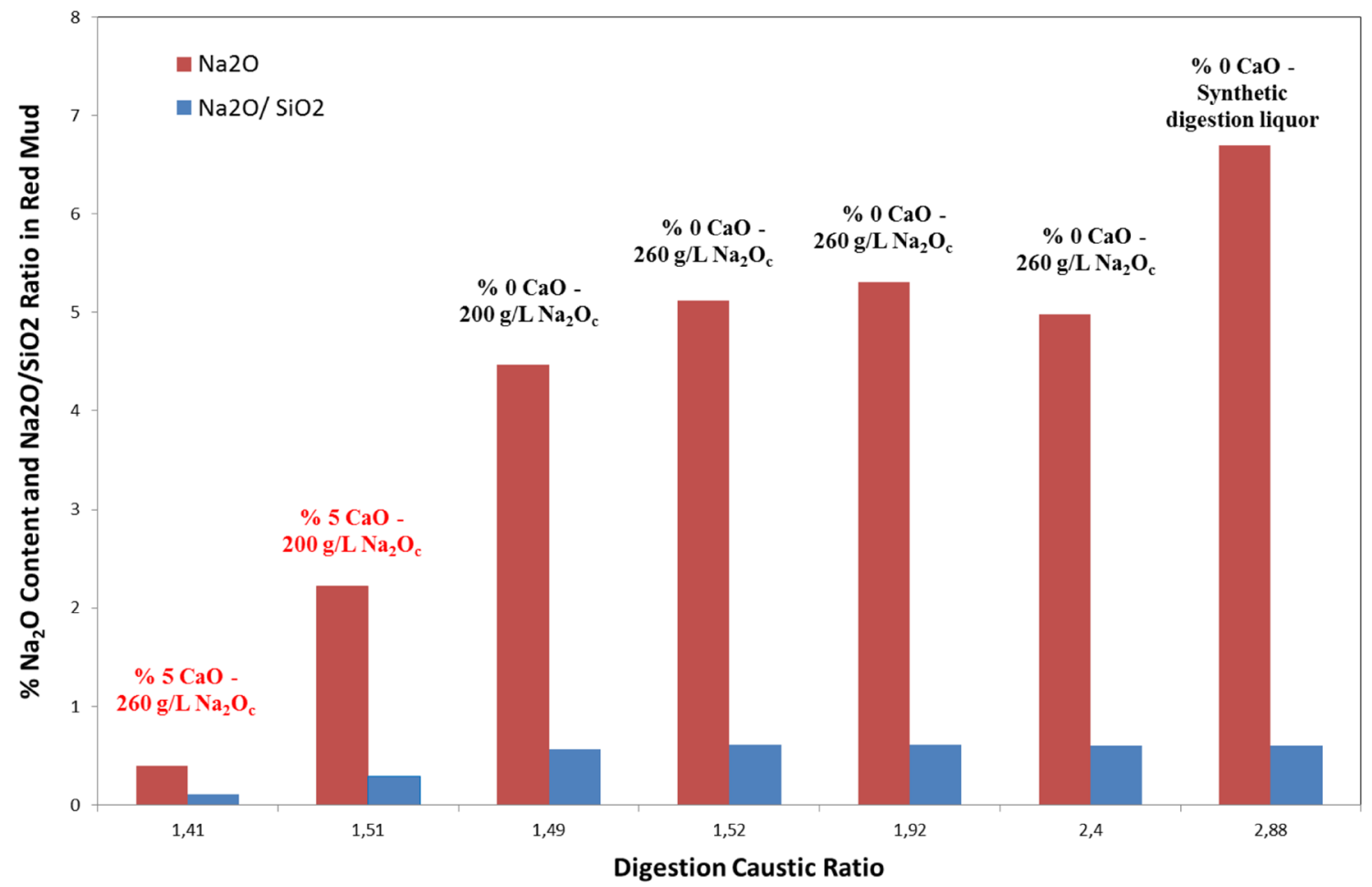

Fig. 5 Red mud caustic content values at different caustic concentrations and ratios with and without lime 


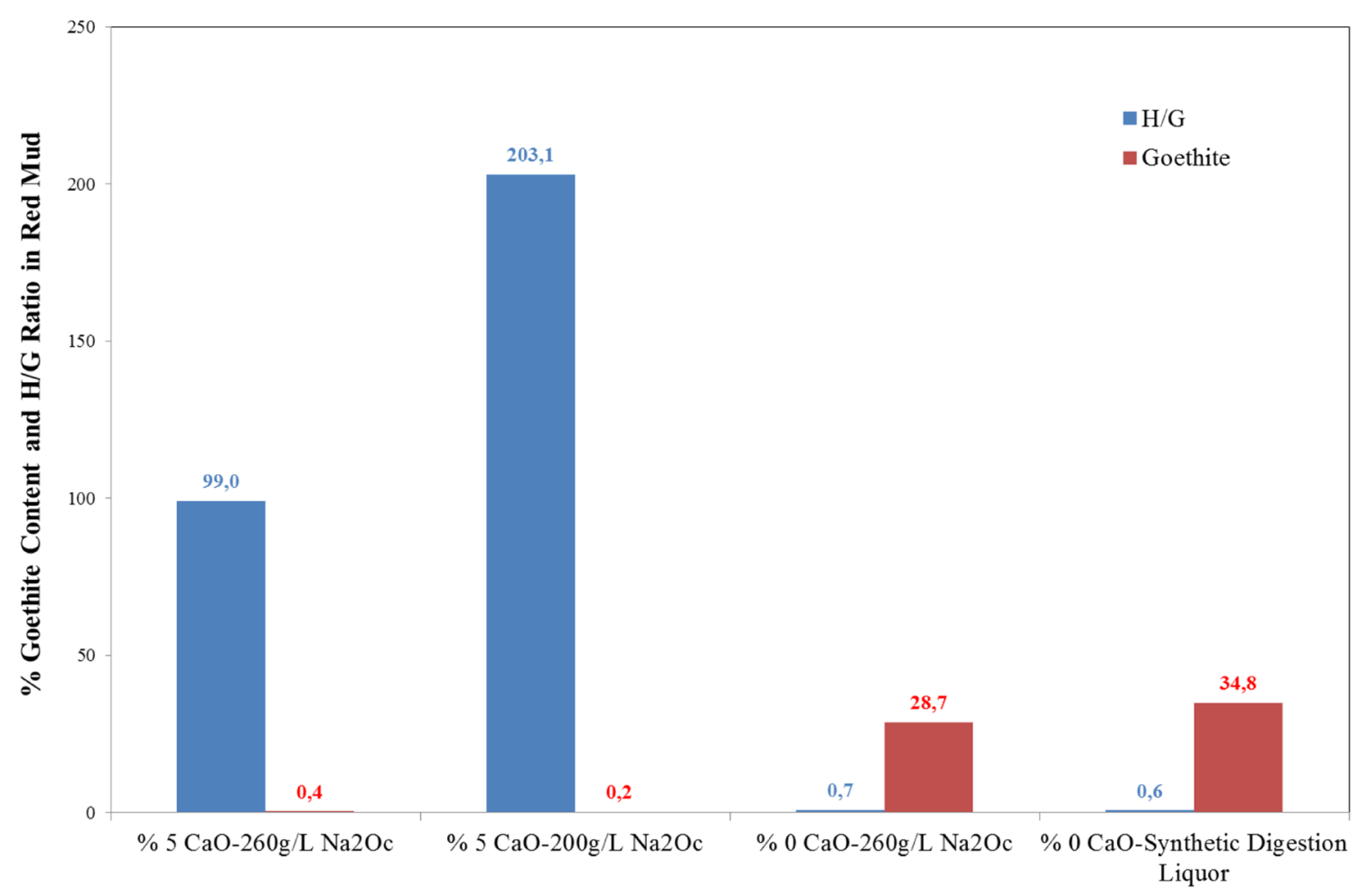

Fig. 6 Red mud $H / G$ ratio at different caustic concentrations with and without lime

22]. It can be seen in Fig. 6 that $5 \%$ lime addition is sufficient to get about $100 \%$ conversion, and also red mud settled much more easily when lime was used in the process.

\section{Settling tests}

The digested slurry from Bauxite-1 was taken and used for settling tests. Firstly, the red mud from each sample was analysed to measure particle size distribution (Table 3) and then they were treated with certain dosages of coagulant and flocculants, followed by settling tests.

The settling characteristics of red mud are mostly dependent on bauxite type as well as digestion conditions. Increasing temperature causes finer particles. Lime addition improves the coarseness of red mud even at higher temperatures and enhances settling and auto-precipitation through the red mud washing system [22, 23].

The settling rates of red mud and suspended solids of overflow liquors are given in Figs. 7, 8, respectively.

In the presence of lime, higher settling rates have been observed. While digestion temperature adversely affects the settling in case of no lime usage, there seems to be no big difference when lime is used. Cytec flocculant (Cyfloc 1229) gave the best performance with starch as coagulant. Lower suspended solids were achieved with lime usage. However, the lowest suspended solids amount was obtained by only starch usage.

\section{Alumina product quality}

The sodium aluminate liquor obtained either with or without lime usage was decomposed via aluminium hydroxide seed addition through $72 \mathrm{~h}$. The aluminium hydroxide crystals derived from the decomposition reaction were washed and filtered, then put in an oven for calcination at $1000{ }^{\circ} \mathrm{C}$. Finally, the samples were cooled and analysed by XRF to determine the impurity levels (Table 4). The standard deviation ranges of two analyses given in Table 4 were as follows: $\mathrm{Na}_{2} \mathrm{O}$ : $0.003 \%, \mathrm{Fe}_{2} \mathrm{O}_{3}: 0.0005 \%, \mathrm{SiO}_{2}: 0.002 \%, \mathrm{CaO}$ : $0.0008 \%, \mathrm{TiO}_{2}: 0.0004 \%, \mathrm{ZnO}: 0.0002 \%, \mathrm{Ga}_{2} \mathrm{O} 3: 0.0004 \%$, $\mathrm{V}_{2} \mathrm{O} 5: 0.002 \%$.

As expected, especially iron and titanium contents of alumina derived from the lime process are lower than the process without lime. The results are compatible with the results of digestion and settling tests. Lime not only promotes the alumina dissolution, but also enhances the impurity control of the whole process.

\section{Energy efficiency}

Contrary to currently used digestion temperature, lime usage gives processing potential at lower temperatures. It has been determined that lower caustic consumption can be achieved at $240{ }^{\circ} \mathrm{C}$ digestion temperature with acceptable alumina losses (Table 5). 


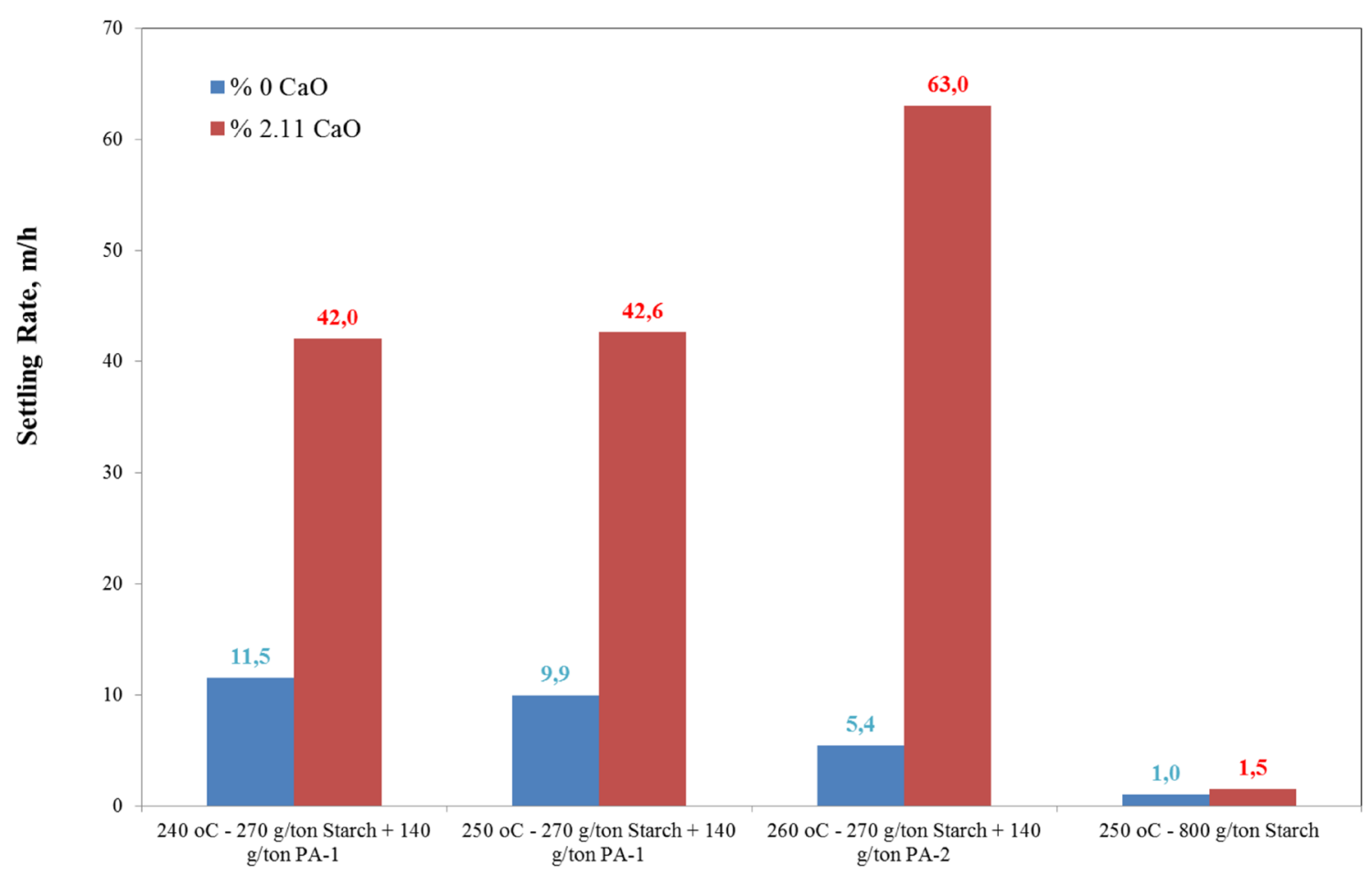

Fig. 7 Red mud settling rates with and without lime

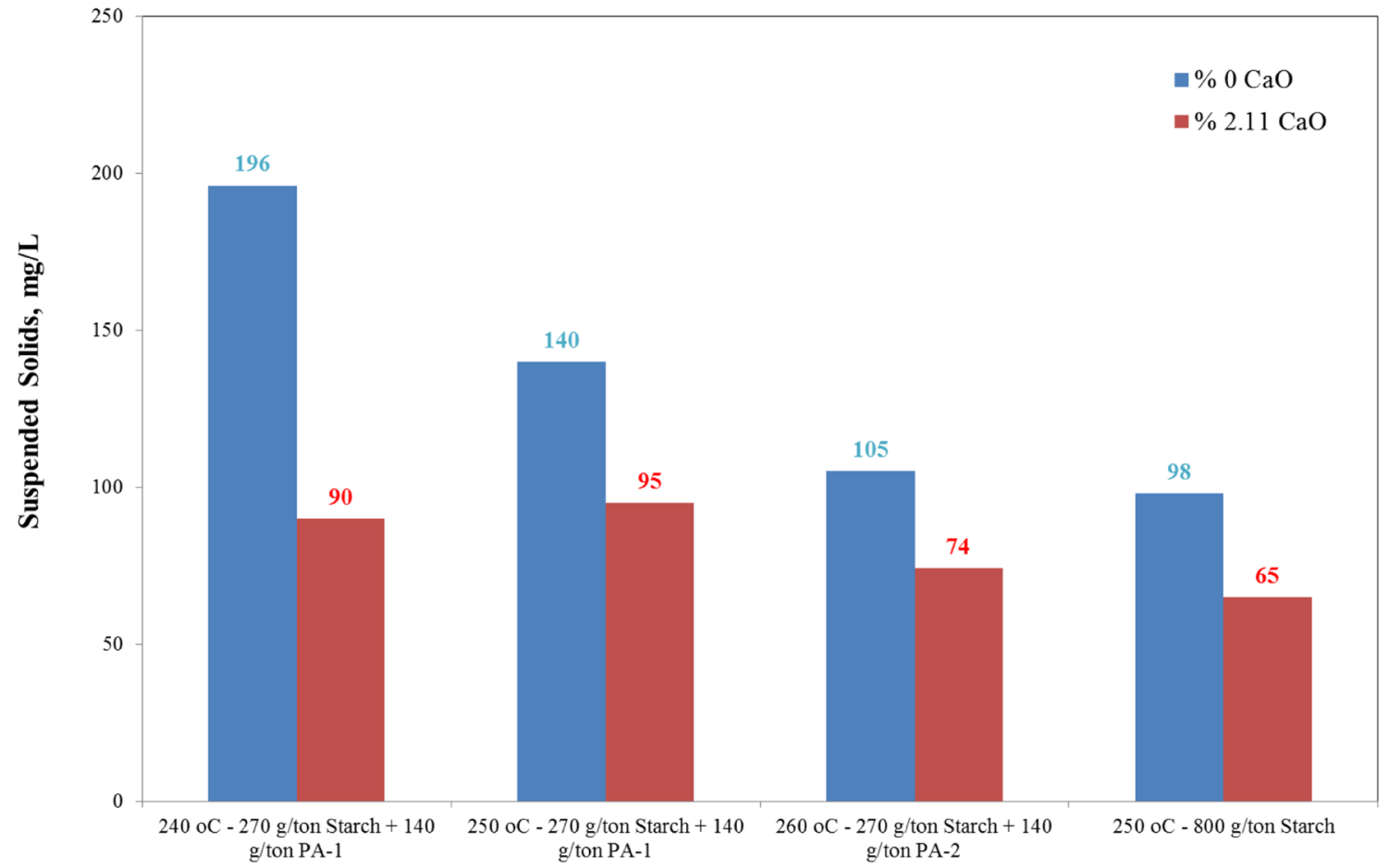

Fig. 8 Overflow liquor suspended solids with and without lime 
Table 4 The chemical analysis of alumina

\begin{tabular}{llllllllll}
\hline Situation & \multicolumn{1}{l}{ Alumina XRF analysis $(\%)$} \\
\cline { 2 - 9 } & $\mathrm{Na}_{2} \mathrm{O}$ & $\mathrm{Fe}_{2} \mathrm{O}_{3}$ & $\mathrm{SiO}_{2}$ & $\mathrm{CaO}$ & $\mathrm{TiO}_{2}$ & $\mathrm{ZnO}$ & $\mathrm{Ga}_{2} \mathrm{O}_{3}$ & $\mathrm{~V}_{2} \mathrm{O}_{5}$ & Total impurity \\
\hline Without lime & 0.114 & 0.0100 & 0.0092 & 0.0052 & 0.0039 & 0.0024 & 0.0091 & 0.00049 & 0.154 \\
With lime & 0.099 & 0.0088 & 0.0099 & 0.0035 & 0.0032 & 0.0024 & 0.0093 & 0.00054 & 0.137 \\
\hline
\end{tabular}

Table 5 Energy efficiency of lime usage

\begin{tabular}{lllll}
\hline Situation & $\begin{array}{l}\text { Bauxite } \\
\text { slurry } \\
\text { specific heat } \\
\left(\mathrm{kcal} / \mathrm{kg}{ }^{\circ} \mathrm{C}\right)\end{array}$ & $\begin{array}{l}\text { Digestion } \\
\text { temperature } \\
\left({ }^{\circ} \mathrm{C}\right)\end{array}$ & $\begin{array}{l}\text { Alumina } \\
\text { recovery } \\
(\%)\end{array}$ & $\begin{array}{l}\text { Specific } \\
\text { steam con- } \\
\text { sumption (ton } \\
\text { steam/ton } \\
\text { alumina) }\end{array}$ \\
\hline $\begin{array}{c}\text { Without } \\
\text { lime }\end{array}$ & 0.734 & 250 & 86.58 & 1.447 \\
With lime & 0.723 & 240 & 82.60 & 1.380 \\
\hline
\end{tabular}

Lime usage provides lower specific steam consumption due to the lower specific heat of slurry treated with lime and also because of lower digestion temperature. However, $4 \%$ of alumina losses should be considered.

\section{Conclusion}

The conclusions of the study are summarized below. Lime usage:

1. Enhances the boehmite and diaspore dissolution rates. It can give an opportunity to process higher diaspore content bauxites in existing plants.

2. Provides a significant decrease of $\mathrm{Na}_{2} \mathrm{O} / \mathrm{SiO}_{2}$ ratio in red mud, which means up to $40 \%$ caustic savings can be achieved.

3. Gives higher settling rates of red mud. It will assist in obtaining a more stable operation of the settler and washer circuit which can result in lower coagulant and flocculant consumptions.

4. Provides about $5 \%$ saving at specific steam consumption.

Additionally, the impurity level of the process liquor can be controlled with lime addition, resulting in $5-15 \%$ alumina product quality improvement.

In summary, lime usage is inevitable, considering the quality change of bauxite at ETI Alüminyum A.S. and the preferred dosage is $10-15 \%$. However, it should be optimized during plant trials.

Acknowledgements The authors would like to thank ETI Alüminyum A.Ş. Management, Alumina Refinery and Quality \& Control Laboratory colleagues for their valuable inputs.
Open Access This article is distributed under the terms of the Creative Commons Attribution 4.0 International License (http://creativeco mmons.org/licenses/by/4.0/), which permits unrestricted use, distribution, and reproduction in any medium, provided you give appropriate credit to the original author(s) and the source, provide a link to the Creative Commons license, and indicate if changes were made.

\section{References}

1. Bayer KJ (1888) Process of obtaining alumina US 382505 A

2. Pan X, Yu H, Dong K, Tu G, Bi S (2012) Pre-desilication and digestion of gibbsitic bauxite with lime in sodium aluminate liquor. Int J Miner Metal Mater 19(11):973-977

3. Kloprogge TJ, Duong LV, Wood BJ, Frost RL (2006) XPS study of the major minerals in bauxite: Gibbsite, bayerite and (pseudo-)boehmite. J Colloid Interface Sci 296(2):572-576

4. Solymar K, Ferenczi T, Papanastassiou D (2002) Digestion alternatives of the Greek diasporic bauxite. In: Schneider W (ed) TMS, light metals-Warrendale-proceedings. TMS, Seattle, WA, pp 75-81

5. Whittington BI, Fletcher BL, Talbot C (1998) The effect of reaction condition on the composition of desilication produce (DSP) formed under simulated Bayer conditions. Hydrometallurgy 49:1-22

6. Baksa G, Vallo F, Sitkei F, Ajka H, Zoldi J, Solymar K (1986) Complex causticisation: an effective means for the reduction of $\mathrm{NaOH}$ losses in an alumina plant. Light Metals 1986:75-80

7. Pan X, Yu H, Tu G (2015) Reduction of alkalinity in bauxite residue during Bayer digestion in high-ferrite diasporic bauxite. Hydrometallurgy 151:98-106

8. Ruan HD, Frost RL, Kloprogge JT (2001) Comparison of Raman spectra in characterizing gibbsite, bayerite, diaspore and boehmite. J Raman Spectrosc 32:745-750

9. Whittington BI (1996) The chemistry of $\mathrm{CaO}$ and $\mathrm{Ca}(\mathrm{OH}) 2$ relating to the Bayer process. Hydrometallurgy 43:13-35

10. Li XB, Zhou QS, Wang HY, Peng ZH, Liu GH (2010) Hydrothermal formation and conversion of calcium titanate species in the system Na2O-A12O3-CaO-TiO2-H2O. Hydrometallurgy 104:156-171

11. Suss A, Fedyaev A, Kuznetzova N, Damaskin A, Kuvyrkina A, Panov A, Paromova I, Lukyanov I (2010) Technology solutions to increase alumina recovery from alumina goethitic bauxites. In: Schneider W (ed) TMS 2010: proceedings and publications. TMS, Seattle, WA, pp 53-56

12. Xu B, Wingate C, Smith PG (2008) The kinetics of quartz dissolution in caustic solutions and synthetic Bayer liquors. Schneider W(Ed) TMS, light metals 2008. TMS, New Orleans, LA, pp 157-161

13. Hollitt M, Kisler J, Raahauge B (2002) The comalco bauxite activation. In: Process proceedings of the 6 th international alumina quality workshop, pp 115-122

14. Gencer E (1984) Bayer metodu ile alümina üretiminde boksit kalitesinin tüketim indislerine etkisi. II. Ulusal Alüminyum Sanayi Kongresi, Seydişehir, pp 41-66 
15. Maltz NS, Sizyakov VM, Shmorgunenko NS (1983) Digestion kinetics of monohydrate bauxite. In: 112 AIME annual meeting, Light metals 1983, Warrendale, Atlanta, GA, pp 99-107

16. Whittington BI, Fallows T (1997) Formation of lime-containing desilication product (DSP) in the Bayer process: factors influencing the laboratory modelling of DSP formation. Hydrometallurgy 45:289-303

17. Whittington BI (1996) Quantification and characterisation of hydrogarnet and cancrinite present in desilication product (DSP) by powder X-ray diffraction. In: 4th international alumina quality workshop-AQW1996, Darwin-Australia, pp 413-422

18. Malts NS, Poddymov VP, Rudashevskii LS, Kiselev VE (1985) The intensifying action of lime upon the kinetics of bauxite leaching. Tsvet Metal 5:38-40

19. Solymar K, Ferenezi T, Papanastassiou D (2004) Digestion of monohydrate bauxite with lime feding at high temperature. In: 15th international symposium of ICSOBA-2004, St. PetersburgRussia, pp 135-141
20. Schulze DG, Schwertmann U (1984) The influence of aluminium on iron oxides. X. properties of Al-substituted goethites. Clay Miner 19:521-539

21. Whittington $\mathrm{BI}(1996)$ The chemistry of $\mathrm{CaO}$ and $\mathrm{Ca}(\mathrm{OH}) 2$ relating to the Bayer process. Hydrometallurgy 43:13-35

22. Wu F (2012) Aluminous goethite in the Bayer Process and its impact on alumina recovery and settling. Curtin University Faculty of Science and Engineering, Ph.D. Thesis, Perth, Australia

23. Rousseaux JM (2006) Milk of lime use in red side settling of Bayer alumina plants. In: 17th international symposium of ICSOBA-2006, Montreal-Canada, pp 194-204

Publisher's Note Springer Nature remains neutral with regard to jurisdictional claims in published maps and institutional affiliations. 